\title{
ECONOMIC EVALUATION FOR HEALTH ADVOCACY AND INFORMED POLICY
}

\section{Evaluasi Ekonomi untuk Advokasi Kesehatan dan Kebijakan yang Diinformasikan}

\author{
*Maznah Dahlui'1,2, Thinni Nurul Rochmah'2,3, Ernawaty²,3, Djazuly Chalidyanto² \\ ${ }^{1}$ Centre of Population Health, Department of Social and Preventive Medicine, Faculty of Medicine, \\ University of Malaya, Kuala Lumpur, Malaysia \\ ${ }^{2}$ Department of Health Policy and Administration, Faculty of Public Health, Universitas Airlangga, Surabaya, \\ Indonesia \\ ${ }^{3}$ The Airlangga Centre for Health Policy Research Group, Surabaya, Indonesia \\ ${ }^{*}$ Correspondence: \\ Address: University of Malaya, 50603, Kuala Lumpur, Malaysia | e-mail: maznahd@ummc.edu.my
}

\begin{abstract}
Background: Healthcare resources are limited therefore, adequate, appropriate and timely allocation of resources are important. Decision to invest on health care program can be made from the analysis of the information obtained on the cost and consequences of the various alternative health programs, often known as economic evaluation of health interventions. Aims: This write-up emphasizes on the importance of evidence driven policy of health intervention whereby economic evaluation should be performed to indicate whether investment on health intervention would benefit the country.

Methods: Literature review on economic evaluation studies conducted by the first author during her 14 years tenure as academician had been performed. Various studies which applied the cost-effectiveness analysis tools to economically evaluate health interventions and programs in Malaysia and other countries are shared.

Results: The economic evaluation studies cut across different programs such as disease prevention and treatment, public health monitoring and control, and implications of health issues to the healthcare system. Many of the findings have been used for advocacy to shape the delivery of more effective health intervention programs in the country.

Conclusion: The country will benefit from economic evaluation studies which could provide evidence to assist in policy making on health programs for the country.
\end{abstract}

Keywords: economic evaluation, health programs, policy making.

\begin{abstract}
Abstrak
Latar Belakang: Alokasi sumber daya kesehatan yang memadai sangat penting karena sumber daya kesehatan yang terbatas. Keputusan untuk berinvestasi pada program perawatan kesehatan dapat dibuat dari analisis informasi yang diperoleh tentang biaya dan konsekuensi dari berbagai program kesehatan alternatif, yang disebut sebagai evaluasi ekonomi intervensi kesehatan

Tujuan: Tulisan ini menekankan pada pentingnya kebijakan intervensi kesehatan berbasis bukti dimana evaluasi ekonomi harus dilakukan untuk menunjukkan apakah investasi pada intervensi kesehatan akan menguntungkan negara.

Metode: Tinjauan pustaka tentang studi evaluasi ekonomi yang dilakukan oleh penulis pertama selama 14 tahun masa jabatannya sebagai akademisi. Penelitian yang dibahas adalah berbagai studi yang menerapkan instrumen analisis efektivitas biaya untuk mengevaluasi intervensi dan program kesehatan secara ekonomis di Malaysia dan negara-negara lainnya

Hasil: Studi evaluasi ekonomi melintasi berbagai program seperti pencegahan dan pengobatan penyakit, pemantauan dan pengendalian kesehatan masyarakat, dan implikasi masalah kesehatan terhadap sistem perawatan kesehatan. Banyak hasil penelitian yang telah digunakan untuk advokasi membentuk pelaksanaan program intervensi kesehatan yang lebih efektif di negara ini.

Kesimpulan: Negara akan mendapatkan manfaat dari studi evaluasi ekonomi dengan memberikan bukti untuk membantu dalam pembuatan kebijakan program kesehatan untuk negara.
\end{abstract}

Kata kunci: evaluasi ekonomi, pembuatan kebijakan, program kesehatan. 


\section{Introduction}

Globally, economic evaluation is gaining prominence as a potential tool for advocacy in health care programs. Economic evaluations can inform decisions concerning the efficiency and allocation of resources to implementation strategies which are explicitly designed to inform care providers and patients about the best available research evidence and to enhance its use in their practices. These strategies are increasingly popular in health care, especially in the light of growing concerns about quality of care and limitation of resources. However, such concerns have hardly driven health authorities and other decision-makers to spend on some form of economic evaluation in their assessments of implementation strategies.

Economic evaluation strives to analyze inputs (health resources) and outputs (changes in health outcomes) concurrently and thus provide the decision/policy maker a yardstick as to whether the outputs level achieve worth the number of resources used to produce it, bearing in mind that resources are scarce and have alternative uses (Drummond et al., 1998). It provides basis for decision between alternative strategies, programs or projects that have different costs and consequences. This helps in ensuring that the limited resources are properly allocated such that the benefits of such programs are worth the costs.

The goals of economic evaluation are to measure efficiency, or the value of money utilized on one health intervention program in comparison to another and also to provide advice to decision-makers or stakeholders on health care intervention program; thus, help in the healthcare resources allocation. Decision on health care program can be made based on the information obtained on the cost and consequences (outcome) of the various alternative health programs/ strategies (Cunningham, 2000). Morris et al. (2012), advanced four reasons for employing economic evaluation in health care decision making thus: 'maximization of benefits from health care spending; overcoming regional variations in access; to contain costs and manage demand; to provide bargaining power with suppliers of healthcare products'.

Economic evaluation starts with assessing the effectiveness of a program and its alternative. Evaluation encompasses the set of tools that are used to measure the effectiveness of public health interventions by determining what works. Traditional evaluations in public health have focused on assessing the impact of specific program activities on defined outcomes. Economic evaluation entails a sound evaluation on the effectiveness of a health programs before incorporating the cost to determine which of the intervention is cost-effective. Ideally, we should perform cost-effectiveness analysis on a health intervention before a policy is made on its implementation. Since performing such analysis can be difficult, often determining the effectiveness and cost of intervention separately would be sufficient when data are not complete (Drummond et al., 1998).

This write-up is on the various economic evaluation that were conducted throughout the tenure of the first author as an academician which cut across different programs such as disease prevention and treatment, public health monitoring and control, and implications of health issues to the healthcare system. This write-up emphasizes on the importance of evidence driven policy of health intervention whereby economic evaluation should be performed to indicate whether investment on health intervention would benefit the country. Many of the findings have been used for advocacy to shape the delivery of more effective health intervention programs. The sharing of the studies aims to encourage the young researchers to conduct economic evaluation studies with policy implications.

\section{Analysis and Discussion}

Economic evaluation should be performed on health programs that are proven to be effective. Often economic evaluation is performed when decision has to be made in selecting a health program among several programs. However, there are situations in which we need to decide 
whether programs that had been implemented for decades should be continued. This warrants a study to evaluate its effectiveness before new health programs can be introduced. A good example of evaluating the effectiveness of a program could be seen from a study which was conducted to assess the adequacy of care and pregnancy outcomes for the different risk groups among women attending antenatal care at public health facilities in Malaysia (Yeoh et al., 2015). The program had been in place for decades and there is a need to study whether the schedule for visits and content of check-up would need to be improvised. It was observed that the usual risk-oriented approach often results in a tendency to focus on the risk conditions of the women resulting in disproportionate utilization of antenatal care according to risk level. From the study, it was concluded that the existing antenatal care warrants for better scheduling and improvement of its contents (Yeoh, Hornetz and Dahlui, 2016).

Many policies had been developed and adopted to combat obesity and NCD in general. However, the effectiveness of the planned health interventions would not be possible if implementation is not carried out accordingly. Therefore, a study was conducted to determine the availability and assess level of implementation of policies for prevention of obesity among children in Malaysia. It was found that relevant policies on obesity prevention are adequate however their implementation need improvement especially by the school canteen operators (Chan et al., 2018). Once implementation of the program has been established, evaluation of their effectiveness can be performed. However, the planning for the evaluation should be made even before the implementations take place so that relevant data would not be missed.

It is imperative to quantify the burden of diseases before the application of any intervention so that the effectiveness of the proposed intervention could be assessed. The estimation of Hepatitis $C$ as a disease burden to the Malaysia (McDonald et al., 2014) had been conducted so that economic analysis can be performed to determine the most cost-effective treatment of Hepatitis C patients in our country. Similarly, assessing the change in the trends of HIV as a disease burden was long overdue; the Harm Reduction Program (HRP) for HIV under the National HIV Control Strategies had been implemented for decades and the World Health Organization (WHO) need to decide whether the financial assistance given for the program is worth to be continued. The study had showed that HRP had reduce the incidence of HIV in the country (Hiebert et al., 2020) and the evidence had been updated recently (Naning et al., 2014). Thus, sponsored by the World Bank, an economic evaluation was conducted in collaboration with researchers from Australia to study whether there was return of investment of the HRP to the country. The researchers had justified that the program is worthy to continue as every 1 Ringgit Malaysia (RM) spent, there is 10 cents in return from direct medical cost which will become RM1.07 in 10 years' time (Hiebert et al., 2020).

It is important to know the cost of any consequences; either a disease or the intervention to treat or prevent a disease. It starts with identification of the type and assessing the quantity of resources used. With those, the cost could be estimated, and subsequent allocation and distribution of resources could be planned. An elaborated cost study was performed to determine the cost and cost predictors of patients undergoing percutaneous coronary intervention $(\mathrm{PCl})$ at University Malaya Medical Center (UMMC), in comparison with other cardiac centers in Malaysia. There are many $\mathrm{PH}$ implications derived from the findings of this study. On the government side, it provides evidence on cost-effectiveness of PCls and how prioritization of budget and allocation of personnel should be made (Lee, Ong, et al., 2017). These are important to maintain an equitable basis for financing health services in the face of escalating health care cost. For the participating cardiac centers, the comparative analysis of clinical and cost management was able to show the areas of improvement that are necessary to improve efficiency of service provision (Lee, Azman, et al., 2017). 
Getting the cost of a program or treatment faces many obstacles not only because of the lack of data and appropriate accounting system but also because confidentiality and sensitivity are issues which need to be considered. However, cost finding is important since it a part of cost-effectiveness analysis. A cost analysis was performed at UMMC, a teaching hospital in 2012 to determine the cost per diem at the various wards, the day-care and for outpatient visit (Dahlui, Wan and Koon, 2012). This cost had been utilized to obtain the cost for treatment of several diseases treated at UMMC such as the cost to treat breast cancer, upper gastrointestinal adverse events in rheumatoid patients (Pok et al., 2021) and in determining whether HLA-B*15:02 screening is a cost-effective option among relatives of breast cancer patients (Chong et al., 2017).

The aim of economic evaluations of health care programs is to serve as an aid to decisions and to affect policymaking. If economic evaluations of health care programs are not going to have any impact on decisions on the allocation of resources to health care interventions, this is a pointless activity. Economic evaluations are used as aids to the development of treatment guidelines, judgements within healthcare organizations, introduction of new medical technologies, reimbursement decisions, and pricing decisions. Before a decision is made on whether a particular intervention i.e pharmaceuticals can be reimbursed, there is a need to ensure that the intervention is cost-effective, and that the cost-effectiveness threshold as determined by the sponsor is met. The World Health Organization had recommended that cost-effectiveness information, including thresholds, should be used alongside other findings, such as budget impact analyses and feasibility studies in the adoption or reimbursement of any health interventions (Bertram et al., 2016). Several European countries including France and Australia had used cost-effectiveness information alongside other types of information to aid different policy decisions especially on the reimbursement of pharmaceuticals from public funds (Hailey, 1997; Le Pen, 1997), 18. A full economic evaluation looks at the benefits and the cost in obtaining the benefits, simultaneously. Evidence of efficiency derived from an economic evaluation of a health program can play a significant role in priority settings and coverage decisions of such a program. Three basic approaches to economic evaluation are cost-effectiveness analysis (CEA), cost-utility analysis (CUA), and costbenefit analysis (CBA) (Drummond et al., 1998; Cunningham, 2001).

The first full economic evaluation that the first author had conducted was in 2005 as her $\mathrm{PhD}$ thesis to determine whether it would be more cost-effective for Ministry of Health (MOH) to subsidize Desferrioxamine (iron chelator drug) to Transfusion-Dependent Thalassemia Patients (TDTP). The findings showed that although the drug was expensive, Quality of Life scores were higher among TDTP on Desferrioxamine compared to none and that the cost to treat the complications of iron overload was much higher than the cost to treat TDTP with Desferrioxamine (Dahlui et al., 2007; 2009). The MOH had considered these findings to justify in getting the drug listed and since 2010 Desferrioxamine is available for free at all government hospitals in Malaysia.

Libya as a developing country was burdened with a high incidence of diarrhoea among her children, of which majority was due to rotavirus infection especially in children under 5 years old. To justify for application of financial assistance from WHO for rotavirus vaccination program in the country, together with a local researcher, a CEA of introducing Rotavirus Vaccine in Libya was conducted. The findings revealed that rotavirus vaccination would be a very cost-effective program to reduce the incidence of rotavirus infection and diarrhoea in general (Alkoshi et al., 2015; Alkoshi, Maimaiti and Dahlui, 2014). These findings led to the Libyan government decided to provide the vaccine for free to all children below 5 in Libya, even without financial aids from WHO.

In $2012 \mathrm{MOH}$, Malaysia wanted to increase the uptake of PAP smear as cervical screening among women in the population, and a pilot project was conducted in the heavily populated Klang district of Selangor whereby women in the 
community were called to attend cervical screening via letter; similar to what had been done under UK NHS. Thus, a CEA was conducted to compare the various mode of calling women to come for PAP smear and the study found that between the invitation via letter posted, registered letter, sending message via SMS and talk to them via telephone call, the women would respond better if they were invited via phone as talking to them personally made them feel that they are cared for (Abdul Rashid et al., 2014).

In 2015, an economic evaluation had also been conducted to determine the cost of various breast cancer screening types in Malaysia and to see whether its worth for $\mathrm{MOH}$ to provide mammogram as a community screening for breast cancer. We found that the current practice of clinical breast examination (CBE) followed by mammography when abnormality is detected, was still relevant and mammogram of women with risks would be more cost-effective than to implement mammogram as community screening of breast cancer. This is because mammogram machine is expensive and the healthcare system had no adequate health personnel (radiographer and radiologist) to perform the screening. It is recommended that efforts should be focused on improving the participation rate for CBE and increasing the budget allocation for mammogram performed on women with breast abnormality and women with risk factors of breast cancer (Ramli, 2017).

In 2017, a study conducted on the "Economic impacts of Haze to Health in Malaysia", was able to inform the resources needed and economic burden in treating the common diseases such as headache, redness of eyes, flu and asthma consequent to the periodic haze situations in the country. This was not a costeffectiveness analysis study since it was not about choosing the best intervention to overcome the health impact of haze, instead was to estimate the cost to treat the illnesses imposed by haze to human health. We found that the incidence of the symptoms and diseases from exposure to haze were significantly higher during haze compared to non-haze seasons. The findings from the study are potential for usage for the preparation of the healthcare system in facing future haze incidence (Jaafar, 2019).

Before 2019, it was unfortunate that Hepatitis C patients in Malaysia did not get the appropriate treatment for their conditions since the Drug Acting Antivirals (DAA) for Hepatitis C patients were not readily available and accessible to them. Serological surveillance was not nationwide and as such it was difficult to estimate the prevalence of Hepatitis C patients needed DAA. In collaboration with the $\mathrm{MOH}$ and several researchers from overseas, they were able to estimate and project Hepatitis $\mathrm{C}$ prevalence in Malaysia (Hassan and Chan, 2020) and performed a budget impact analysis for the government to subsidize DAA for proper management of Hepatitis C of affected Malaysian. The findings were able to justify on the investment for life-long treatment of the disease which can be exorbitant (Hiebert et al., 2019).

Presently, with the Covid 19 pandemic affecting the country, an economic evaluation works in progress to determine the disease and economic burdens of Covid 19 in the country, especially on its implications to the healthcare system. The grant for this study was awarded by the Ministry of Science and Technology as a recognition on the various economic evaluations that the first author had performed. In addition, she is currently leading the Malaysia research team in CoMo or Covid 19 Modelling Consortium set up by the University of Oxford to model the infection under various health interventions and lockdowns imposed by more than 20 countries joining CoMo. The CoMo team had published on the potential health and economic impacts of dexamethasone treatment for patients with COVID-19 (Ku Abd Rahim et al., 2020).

\section{Conclusion}

The country, especially the ministry of health could highly benefit the findings from economic evaluations on the health programs conducted by academicians and researchers. Findings from economic evaluation studies, coupled with feasibility 
and cultural adaption assessment should be used and translated into policy for a sustainable implementation of health interventions. Collaborations between the various stakeholders and the program owners to provide evidence to assist in policy decision on which health interventions to be invested and implemented, should be enhanced. In Malaysia, the Health Technology Division of Ministry of Health (MAHTA) has developed the platform for this collaboration and as a team, some technical issues on economic evaluation studies have been discussed and obtained solutions. It is very encouraging when the findings from various locally conducted CEA studies are used by MAHTA to set the CEA threshold for accepted health interventions in the country (Águas et al., 2021). By sharing these economic evaluation studies conducted in Malaysia, it is hope that researchers in the neighbouring countries such as Indonesia which has similar resources limitations are aspired conduct similar economic evaluation studies of health programs and advocate the use of the relevance findings for policy making in the country.

\section{Abbreviations}

HRP: Harm Reduction Program; WHO: World Health Organization; PCl: Percutaneous Coronary Intervention; UMMC: University Malaya Medical Center; CEA: Cost-Effectiveness Analysis; CUA: Cost-Utility Analysis; CBA: Cost-Benefit Analysis; TDTP: Transfusion-Dependent Thalassemia Patients; DAA: Drug Acting Antivirals: CBE: Clinical Breast Examination; CoMo: Covid 19 Modelling Consortium; MAHTA: Health Technology Division of Ministry of Health.

\section{Declarations}

\section{Ethics Approval and Consent Participant Not applicable}

\section{Conflict of Interest}

We declare that we do not conflict with anyone's interest.

\section{Availability of Data and Materials}

Not Applicable

\section{Authors' Contribution}

MD had developed the manuscript. TNR, E and $D C$ review the manuscript.

\section{Acknowledgment}

The author wishes to acknowledge her research team members in all the studies that were conducted either as a student's thesis or research project, and the coauthors of this research review

\section{References}

Abdul Rashid, R. M. et al. (2014) 'Cost effective analysis of recall methods for cervical cancer screening in Selangor - Results from a prospective randomized controlled trial', Asian Pacific Journal of Cancer Prevention, 15(13), pp. 5143-5147. doi: 10.7314/APJCP.2014.15.13.5143.

Águas, R. et al. (2021) 'Potential health and economic impacts of dexamethasone treatment for patients with COVID19', Nature Communications, 12(1), pp. 1-8. doi: 10.1038/s41467-02121134-2.

Alkoshi, S. et al. (2015) 'Anticipating rotavirus vaccines - A pre-vaccine assessment of incidence and economic burden of rotavirus hospitalizations among children $<5$ year of age in Libya, 2012-13', BMC Public Health, 15(1), pp. 1-6. doi: 10.1186/s12889-015-1400-7.

Alkoshi, S., Maimaiti, N. and Dahlui, M. (2014) 'Cost-effectiveness analysis of rotavirus vaccination among Libyan children using a simple economic model', The Libyan journal of medicine, 9, p. 26236. doi: 10.3402/ljm.v9.26236.

Bertram, M. Y. et al. (2016) 'Policy \&amp; practice Cost-effectiveness thresholds: pros and cons Thresholds based on gross domestic product', Bull World Health Organ, 94(September 2015), pp. 925-930. Available at: http://dx.doi.org/10.2471/BLT.15.164 418. 
Chan, C. et al. (2018) 'Awareness, Facilitators, and Barriers to Policy Implementation Related to Obesity Prevention for Primary School Children in Malaysia', American Journal of Health Promotion, 32(3), pp. 806-811. doi: $10.1177 / 0890117117695888$.

Chong, H. Y. et al. (2017) 'Is universal HLA$B * 15: 02$ screening a cost-effective option in an ethnically diverse population? A case study of Malaysia', British Journal of Dermatology, 177(4), pp. 1102-1112. doi: $10.1111 /$ bjd.15498.

Cunningham, S. J. (2000) 'Economic evaluation of healthcare - is it important to us?', British Dental Journal, 188(5), pp. 250-254. doi: 10.1038/sj.bdj.4800444.

Cunningham, S. J. (2001) 'Current products and practice: An introduction to economic evaluation of health care', Journal of Orthodontics, 28(3), pp. 246-250. doi: 10.1093/ortho/28.3.246.

Dahlui, M. et al. (2007) 'Desferrioxamine treatment in thalassaemia: A cost utility analysis', Malaysian Journal of Public Health Medicine, 7(2), pp. 4-9. Available at: https://www.researchgate.net/publica tion/287188883_Desferrioxamine_tr eatment_in_thalassaemia_A_cost_ut ility_analysis.

Dahlui, M. et al. (2009) 'Quality of life in transfusion-dependent thalassaemia patients on desferrioxamine treatment', Singapore Medical Journal, 50(8), pp. 794-799.

Dahlui, M., Wan, N. C. and Koon, T. S. (2012) 'Cost analysis of UMMC services: estimating the unit cost for outpatient and inpatient services', BMC Health Services Research, 12(S1), pp. 1-2. doi: 10.1186/14726963-12-s1-01.

Drummond, M. F. et al. (1998) 'Methods for the Economic Evaluation of Health Care Programmes, Second Edition', American Journal of Preventive Medicine, 14(3), p. 243. doi: 10.1016/S0749-3797(97)00069-X.

Elsinga, E. and Rutten, F. F. H. (1997) 'Economic evaluation in support of national health policy: The case of the Netherlands', Social Science and Medicine, 45(4), pp. 605-620. doi: 10.1016/S0277-9536(96)00400-5.

Hailey, D. (1997) 'Australian economic evaluation and government decisions on pharmaceuticals, compared to assessment of other health technologies', Social Science and Medicine, 45(4), pp. 563-581. doi: 10.1016/S0277-9536(96)00397-8.

Hassan, M. R. A. and Chan, H. K. (2020) 'Projections of the Healthcare Costs and Disease Burden due to Hepatitis C Infection Under Different Treatment Policies in Malaysia, 2018-2040', Applied Health Economics and Health Policy, 18(1), pp. 139-140. doi: 10.1007/s40258-019-00543-x.

Hiebert, L. et al. (2019) 'A Stepwise Approach to a National Hepatitis C Screening Strategy in Malaysia to Meet the WHO 2030 Targets: Proposed Strategy, Coverage, and Costs', Value in Health Regional Issues, 18(Cdc), pp. 112-120. doi: 10.1016/j.vhri.2018.12.005.

Hiebert, L. et al. (2020) 'Estimating the Population Size of People Who Inject Drugs in Malaysia for 2014 and 2017 Using the Benchmark-Multiplier Method', Substance Use and Misuse, 55(6), pp. 871-877. doi: 10.1080/10826084.2019.1708943.

Jaafar, H. (2019) Economic Implications of Haze in Malaysia. University of Malaya.

Ku Abd Rahim, K. N. et al. (2020) 'From Evidence to Policy: Economic Evaluations of Healthcare in Malaysia - A Systematic Review', Value in Health Regional Issues, 21(Cdc), pp. 91-99. doi: 10.1016/j.vhri.2019.09.002.

Lee, K. Y., Azman, W., et al. (2017) 'Comparison of the treatment practice and hospitalization cost of percutaneous coronary intervention between a teaching hospital and a general hospital in Malaysia: A cross sectional study', Plos One, 10, pp. 114.

Lee, K. Y., Ong, T. K., et al. (2017) 'Cost of elective percutaneous coronary intervention in Malaysia: A 
multicentre cross-sectional costing study', BMJ Open, 7(5), pp. 1-10. doi: 10.1136/bmjopen-2016-014307.

McDonald, S. A. et al. (2014) 'Bridging the data gaps in the epidemiology of hepatitis $C$ virus infection in Malaysia using multi-parameter evidence synthesis', BMC Infectious Diseases, 14(1), pp. 1-8. doi: 10.1186/s12879014-0564-6.

Morris, S. et al. (2012) Economic Analysis in Health Care. 2nd editio. London: Wiley.

Naning, H. et al. (2014) Return on Investment and Cost-Effectiveness of Harm Reduction Programme in Malaysia. Available at: https://www.aidsdatahub.org/sites/de fault/files/resource/roi-and-costeffectiveness-harm-reductionprogramme-malaysia.pdf.

Le Pen, C. (1997) 'Pharmaceutical economy and the economic assessment of drugs in France', Social Science and Medicine, 45(4), pp. 635-643. doi: 10.1016/S02779536(96)00402-9.
Pok, L. S. L. et al. (2021) 'Clinical and economic implications of upper gastrointestinal adverse events in Asian rheumatological patients on long-term non-steroidal antiinflammatory drugs Lydia', International Journal of Rheumatic Diseases, 21(05), pp. 24-26. Available at: https://onlinelibrary.wiley.com/doi/10. 1111/1756-185X.13256.

Ramli, S. (2017) Cost and Effectiveness of Mammogram versus Usual Screening of Breast Cancer in Malaysia. University of Malaya.

Yeoh, P. L. et al. (2015) 'Assessing the extent of adherence to the recommended antenatal care content in Malaysia: Room for improvement', PLoS ONE, 10(8), pp. 1-15. doi: 10.1371/journal.pone.0135301.

Yeoh, P. L., Hornetz, K. and Dahlui, M. (2016) 'Antenatal Care Utilisation and Content between Low-Risk and HighRisk Pregnant Women', pp. 1-17. doi: 10.1371/journal.pone.0152167. 